\title{
PERSONAL FINANCE MANAGEMENT IN POLAND FROM 2004-2013
}

\author{
Marta Musiał ${ }^{1}$
}

\begin{abstract}
This article describes the state of household finance management in Poland. The analysis consists of three basic elements of household finance, such as income and expenditure of Polish households, savings and investments of Polish households, and Polish households debt. The presented data represent the time period from 2004 to 2013. The data came from reports of National Central Bank in Poland and Central Statistical Office in Poland. Based on the presented data, it can be said that the situation of Polish household has improved during the analyzed period. Moreover, Polish household characterized risk aversion decision by saving their money mostly in the form of bank deposit or cash.
\end{abstract}

JEL Classification Numbers: D14, D31, L84, DOI: http://dx.doi.org/10.12955/cbup.v3.603

Keywords: personal finance, household finance, savings, credits

\section{Introduction}

The smallest entities of economy are households. However, most researches concern the problems of companies, sectors, or countries. Financial decisions of households influence the whole economy, which can be experienced during the times of crisis. Insolvency of households all over the world is becoming one of the worldwide issues. In case of crisis prevention, it is necessary to analyze the financial situation of households. Based on that assumption, this article presents the basic data concerning personal finance management in Poland, such as income, expenditure, savings, and credit of Polish households.

\section{Theory of personal finance management}

Currently, the prevailing view is that one cannot speak of a single science of finance, but the sciences of finance (Dobosiewicz, 2000), which also include (Miłaszewicz, 2001):

- public finance - the science of the financial operations carried out by the state; mainly deals with fiscal policy;

- banking - the science of banks and their ongoing operations;

- insurance finance - the science of the financial operations in the insurance market;

- corporate finance - the science of the financial operations carried out by the companies, which are essential for the management of companies and their resources;

- household finance - also known as population finance and personal finance.

Personal finance is a relatively new research area; therefore, in the literature, there are very few definitions on this concept. In the foreign literature, more attention is given to topics such as personal finance management or personal finance planning. Most scientists identify the concept of personal finance with the concept of household finance. An example of this phenomenon may be the definition of personal finance by Garman \& Forgue (2008) who thinks that personal finance is the study of personal and family resources that are considered essential to achieving financial success. It applies to savings, spending, and investment protection of people's financial resources. However, some, such as Świecka (2014), believes that personal finance is a narrower concept than household finances and affect private finance. Świecka (2014) suggests a "sensu largo and sensu stricte” approach to personal finance, defining personal finance in the broad sense as a sub-discipline of economic sciences related to the management of financial resources by household members. In this case, the term "personal finance in the broad sense" may be synonymous with the term "household finance." In contrast, in the

\footnotetext{
${ }^{1}$ mgr Marta Musiał, Faculty of management and Economics of Services, University of Szczecin, Poland, marta.musial@wzieu.pl.
} 
strict sense of personal finance, it is a sub-discipline of the science of finance dealing with the acquisition of funds, their collection, and spending by individuals.

According to Kapoor, Dlabay, \& Hughes (2007), personal finance management is a process of continuous management of money, consisting of activities related to the preparation and implementation of monetary operations. The main areas of personal financial management may include (Kapoor et al., 2007; Waliszewski, 2011; Beal \& McKeown, 2003; Callaghan, Fribbance, \& Higginson, 2012):

- obtaining income - to receive resources from employment;

- spending - the purchase of consumer goods;

- savings - depositing money for "rainy day” or toward specific financial goals;

- investing - buying investment products to make a profit;

- lending - borrowing and lending of various kinds;

- $\quad$ risk management - the use of various financial products, eg. insurance or financial strategies to protect property and members of the household;

- retirement planning - depositing and investing money for the future;

- tax planning - skillful use of tax credits;

- wealth transfer - transfer of assets to heirs.

\section{Incomes and expenses of Polish households}

During the analyzed period from 2004-2013, disposable income per person in the household increased from $735.40 \mathrm{zl}$ in 2004 to $1299.07 \mathrm{zl}$ in 2013 (Figure 1). It is much less than the minimum wage in Poland, which amounted to $1600 \mathrm{zt}$ in 2013 (GUS, 2014).

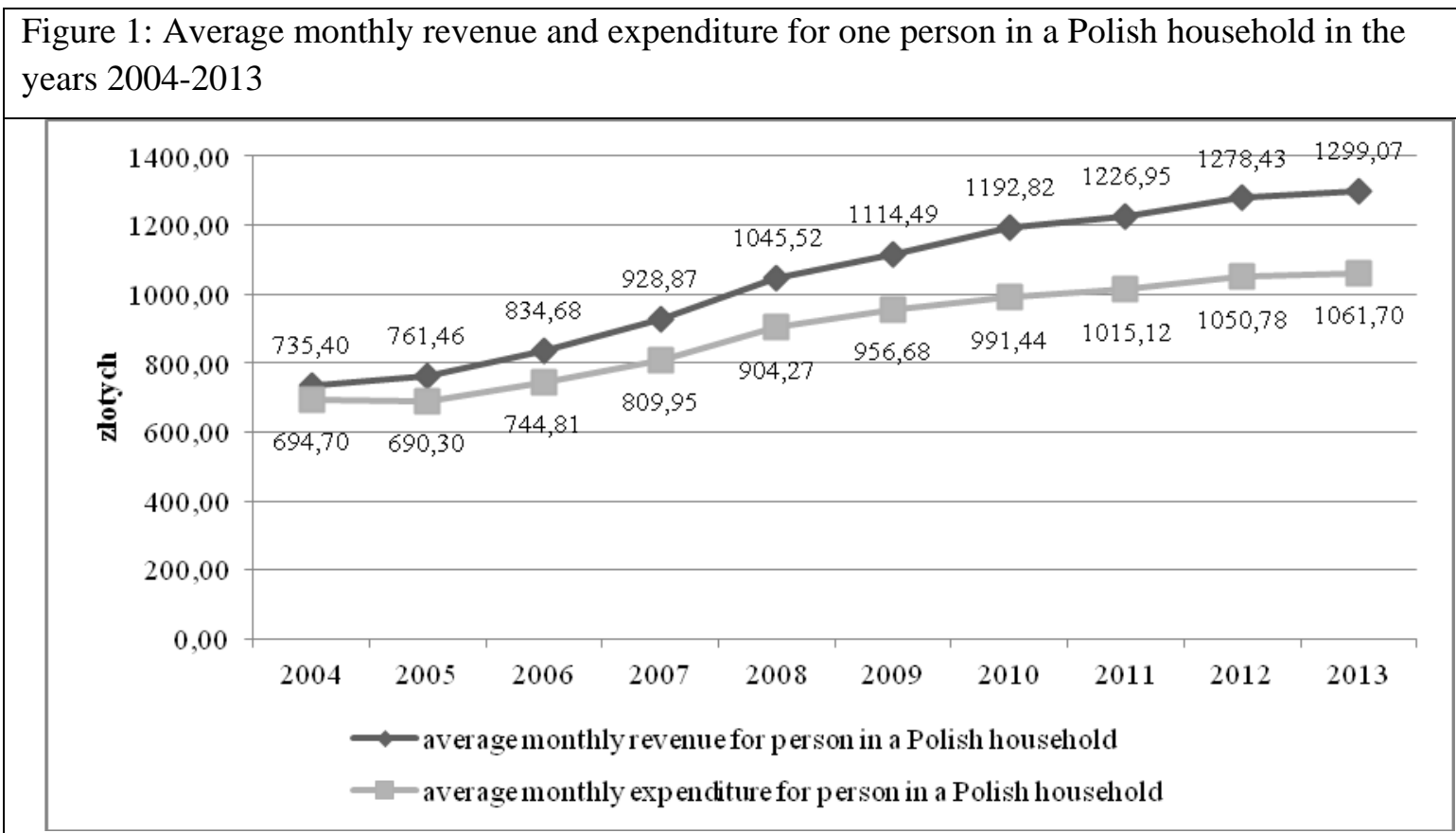

Source: GUS (2013)

In contrast, the total expenditure per person in a household has increased since 2004 from $694.70 \mathrm{zl}$ to $1061.70 \mathrm{zt}$ in 2013. Consequently, the share of expenditure in disposable income has decreased from $95.2 \%$ in 2004 to $81.7 \%$ in 2013. 
The main source of income in Poland is wage labor (53.1\% of total income). Social security benefits and other benefits represent $29.1 \%$ of all revenue of the Poles (pensions account for $20.4 \%$ and annuities for $4.9 \%)$. Income from self-employment is less than $10 \%$, while income from a private farm in agriculture is only $4.4 \%$.

The largest part of the Polish expenditure structure constitutes expenditures on food and non-alcoholic beverages (24.9\%) and expenditures on utilities and energy (20.8\%). Poles spend the least on education (1.2\%); alcoholic beverages, tobacco, and drugs (2.6\%); and hotels and restaurants (2.9\%).

\section{Savings and investments of Polish households}

Macroeconomic factors (including problems in the labor market, the financial crisis, and rising prices) cause that Poles to prefer to save and to protect against a loss of revenue or an increase in spending in the future (precautionary savings motive by J. M. Keynes). At the end of 2012, the Poles' savings were 7\% higher than a year earlier. Since 2004, the Poles' savings has increased by more than two-fold (from 372.1 million $\mathrm{zl}$ in 2004 to 814.5 million $\mathrm{zt}$ in 2012). The share of the Poles' savings in the Polish GDP has been fluctuating around 50\% since 2006. In 2012, it amounted to 51.1\% (figure 2).

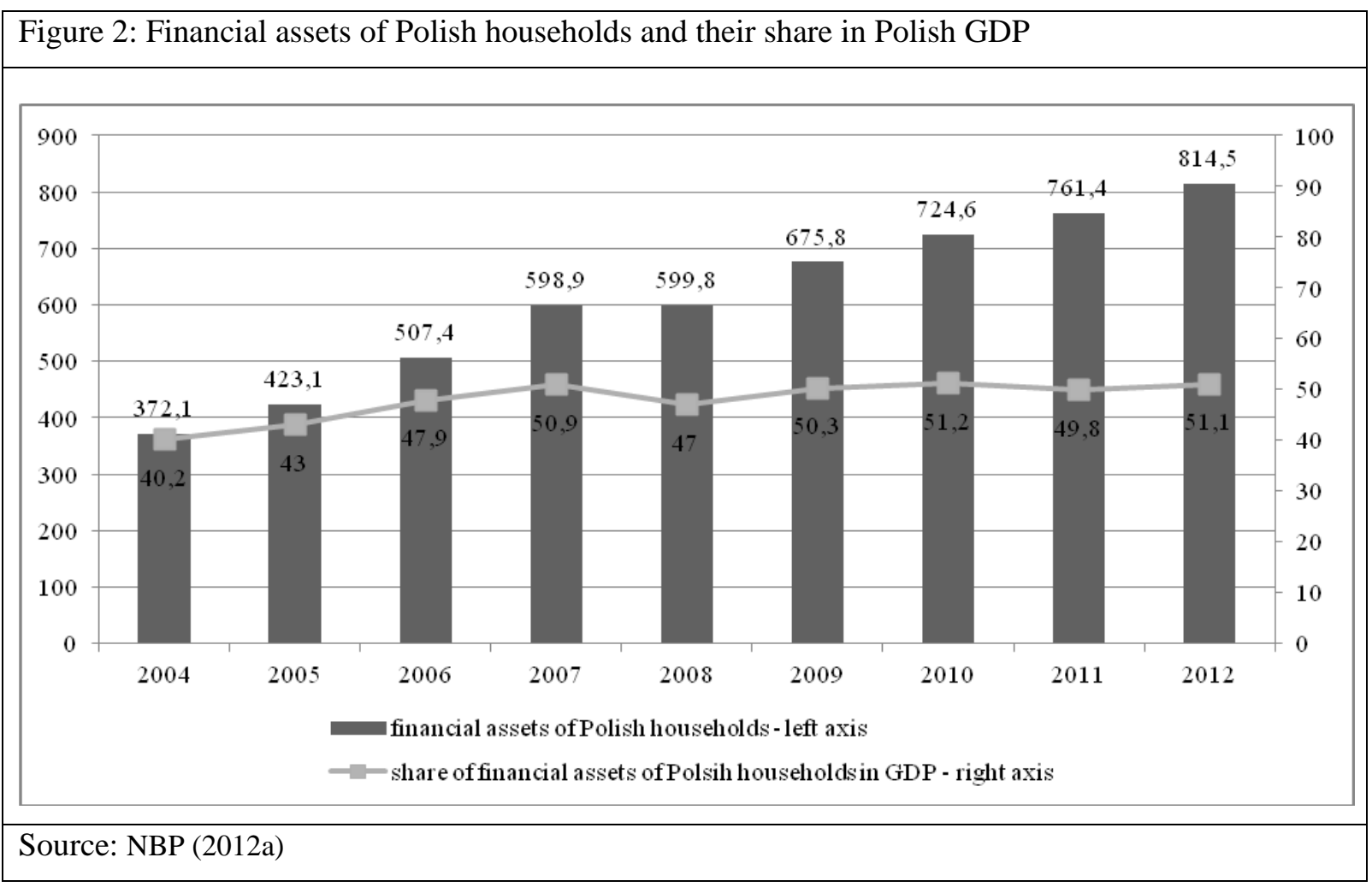

Most Poles hold their savings in bank deposits (almost 60\% in 2012). Unfortunately, a large part of the Poles' savings is being held in the form of cash (12\% in 2012). Less than $10 \%$ of the savings is invested in the form of titles in investment funds and another $10 \%$ in the titles of participation in the form of premium unit-linked and life savings.

\section{Polish household debt}

According to OECD data, from 2004 to 2012, the share of debt in disposable income has increased from $21.1 \%$ to $58.9 \%$, an increase of $37.8 \%$ (Figure 3). In addition, it is worth noting that in 2012, for the first time since 2004, there has been a decline in the share of debt relative to disposable income of the previous year (60.6\% in 2011). 
CBU I NTERNATI ONAL CONFERENCE ON I NNOVATION, TECHNOLOGY TRANSFER AND EDUCATION

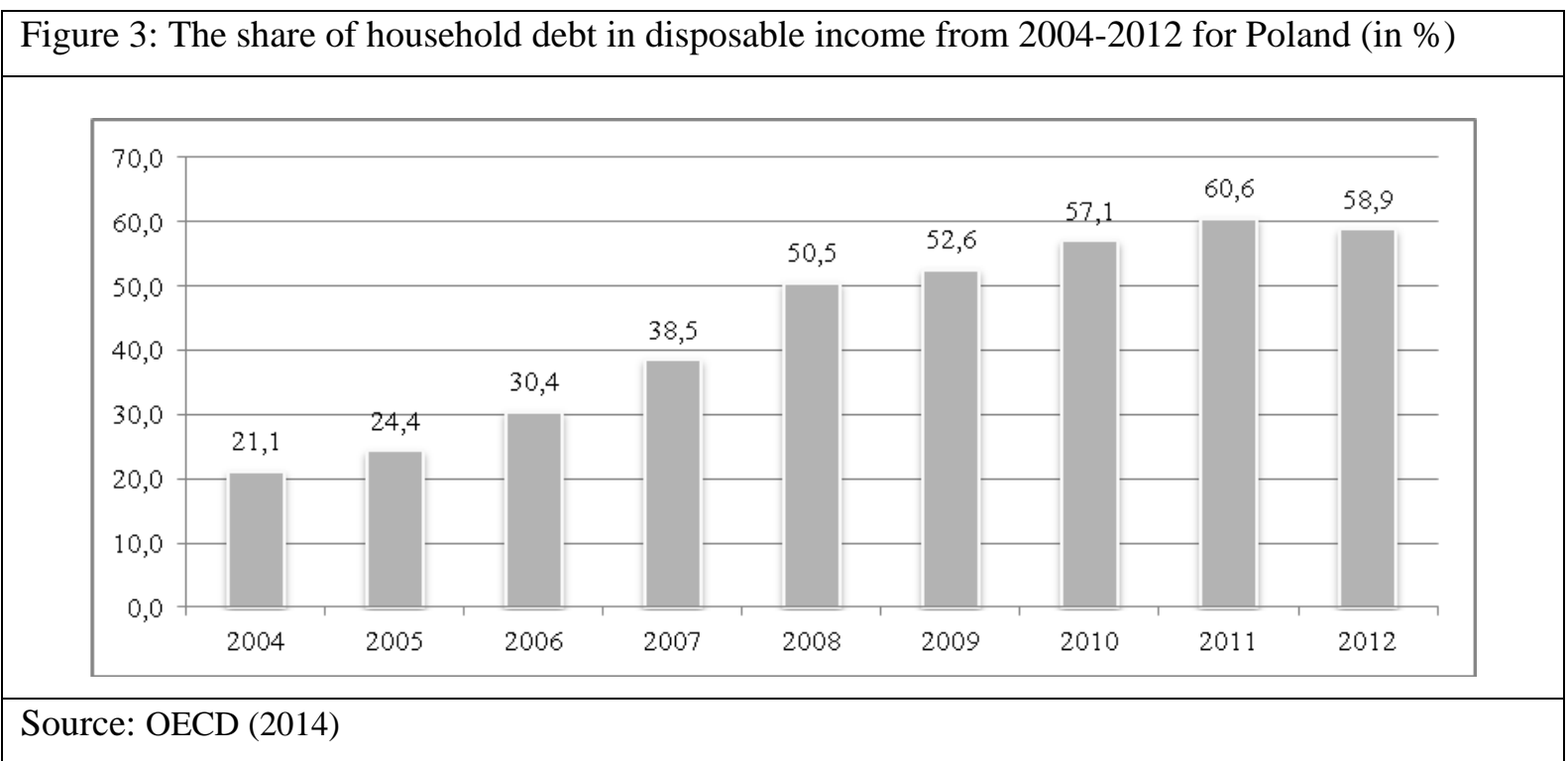

Polish credit behavior can be characterized as follows (Rogowski, 2014):

- $48 \%$ of Poles are active lenders, i.e. have at least one active credit account;

- only a quarter (25\%) of Poles have a consumer credit debt on the average amount of $15276 \mathrm{zt}$. On the other hand, one in every 10 Poles has a mortgage debt in the amount of $111053 \mathrm{zl}$ on the average;

- $10 \%$ of Poles have an active credit card, and the average value of the credit limit on the borrower having a credit card is $6589 \mathrm{zk}$, whereas the average credit limit used in the active card is $58 \%$.

Since 2007, the currency structure of housing loans taken out by households has also changed. The share of loans taken in PLN has increased from approx. 60\% in 2007 to approx. 90\% in 2012. In addition, the Poles take out loans in currencies such as USD, EUR, and CHF (Figure 4).

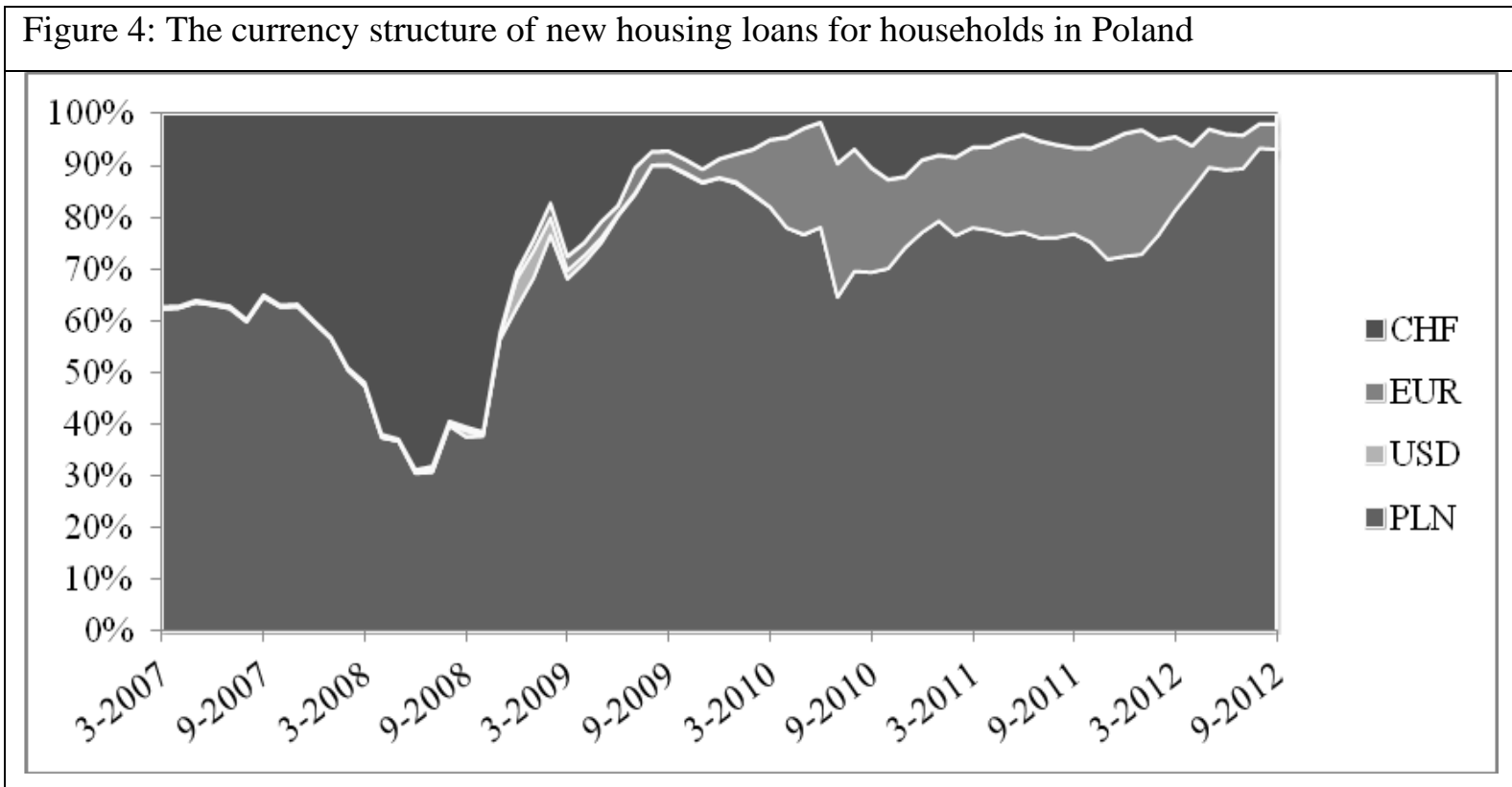

Source: NBP (2012a) 


\section{Conclusion}

Personal finance sensu largo means the same as household finance. This part of financial science concerns the money operations of every type of households (also single household - one person). The money operations include obtaining income, expenditure, savings and investments, credits and loans, and other. To sum up, based on the data presented, Polish household financial situation from 20042013 can be described by the following conclusions:

- Both, disposable income and the total expenditure per person in the household has increased. However, the share of expenditure in disposable income has decreased from 95.2\% in 2004 to $81.7 \%$ in 2013.

- Since 2004, the Poles' savings has increased by more than two-fold, but the share of the Poles' savings in Polish the GDP has been fluctuating around 50\% since 2006.

- The basic form of savings for Polish households are bank deposits and cash.

- Polish household debt has increased from 2004, but only $48 \%$ of the Poles are active lenders.

\section{Acknowledgement}

The article is the result of the research project No. 2013/09/N/HS4/03697 funded by National Science Centre in Poland.

\section{References}

Beal, D., \& McKeown, W. (2003). Personal finance. Milton: John Wiley and Sons.

Callaghan, G., Fribbance, I., \& Higginson, M. (2012). Personal Finance. New York: Palgrave McMillan.

Dobosiewicz Z. (2000). Wprowadzenie do finansów i bankowości [Introduction to finance and banking], Warszawa: PWN.

Garman, E. T., \& Forgue, R. (2008). Personal finance. USA: Houghton Mifflin Company.

GUS (2013). Sytuacja gospodarstw domowych w 2013 r. w świetle wyników badań budżetów gospodarstw domowych [Households situation in 2013 in the scope of households budgets reasearch results]. Retrieved 29 September, 2014, from http://old.stat.gov.pl/gus/5840_1160_PLK_HTML.htm.

GUS (2014). Minimal salary. Retrieved 29 September 2014, from http://wynagrodzenia.pl/gus_placa_minimalna.php

Kapoor, J. R., Dlabay, L. R., \& Hughes, R. J. (2007). Personal finance (8th ed.). New York, McGraw-Hill.

Miłaszewicz, D. (2001). Problemy zarządzania finansami gospodarstw domowych [Household finance management problems], Twój Kapitał 2001, Zachodniopomorskie Forum Finansowo-Kapitałowe, Szczecin, 337.

NBP (2012a). Raportu o stabilności systemu finansowego [Financial system stbility report], NBP, Warszawa. Retrieved 30 January, 2015, from http://www.nbp.pl/home.aspx?f=/systemfinansowy/stabilnosc.html.

NBP (2012b). Raport o rozwoju systemu finansowego w Polsce w 2008, 2012 [Financial system development report in 2008 nd 2012]. Retrieved 29 Septemer, 2014, from http://www.nbp.pl/home.aspx?f=/systemfinansowy/rozwoj.html.

OECD (2014). Factbook 2014: Economic, Environmental and Social Statistics. OECD Publishing. Retrieved 30 January 2015, from http://www.oecd-ilibrary.org/economics/oecd-factbook_18147364.

Rogowski, W. (2014, June). Pokoleniowy portret kredytowy Polaków [Generational portrait of Poles credit]. BIK, Kredyt Trendy [Credit Trends], 30-46.

Świecka, B. (2014). Finanse osobiste jako subdyscyplina finansów [Personal Finance as a finance sub-discipline]. In: B. Świecka (ed.), Wspótczesne problemy finansów osobistych [Contemporary issues of personal finance] (pp. 18). Warsaw: CeDeWu.

Waliszewski, K. (2011). Doradztwo finansowe w Polsce [Financial advice in Poland]. Warszawa: CeDeWu. 